\title{
Comparative Osteometric Study of Long Bones in Yankasa Sheep and Red Sokoto Goats
}

\author{
Estudio Osteométrico Comparativo de los Huesos Largos \\ entre Oveja Yankasa y las Cabras Rojas Sokoto
}

"S. O. Salami; "C. S. Ibe; *A. D. Umosen; *'I. E. Ajayi \& "S. M. Maidawa

SALAMI, S. O.; IBE, C. S.; UMOSEN, A. D.; AJAYI, I. E.\& MAIDAWA, S. M. Comparative osteometric study of long bones in Yankasa sheep and red Sokoto goats. Int. J. Morphol., 29(1):100-104, 2011.

SUMMARY: A morphometric study was undertaken on the long bones in the two predominant breeds of small ruminant in Northern Guinea Savanna zone of Nigeria, to determine their anatomical differences and thus, provide a means of differentiating the remains of these two species during zooarchaeological studies and gross anatomy practical session. The pelvic and pectoral limbs from thirty animals (15 Yankasa sheep and 15 Red Sokoto goats) of both sexes were used for this study. The long bones of the pectoral limbs considered were the humerus, radius, ulna and metacarpal III while those of the pelvic limbs were the femur, tibia and metatarsal III. The parameters considered were the mean weights, lengths and diameters of the proximal extremity, mid-shaft and distal extremities of these bones. The result of this study showed that there is a very high statistically significant difference $(\mathrm{p}<0.001)$ in the length of long bones between the two species, with that of the Yankasa sheep being significantly longer than the Red Sokoto goat. Also, the differences in weights as well as diameters of the proximal, middle and distal shafts of the tibia between the two species are of a very high statistical importance $(\mathrm{p}<0.001)$. Conversely, the differences in the proximal and distal diameters of the femur between the two species are not statistically significant ( $p>0.05$ ). Factors that may be responsible for these differences were discussed. It is concluded that the bones of the Yankasa sheep and Red Sokoto goat can be differentiated by the disparity in the length of these long bones or the disparity in the entire morphometry of the tibia bone.

KEY WORDS: Yankasa sheep; Red Sokoto goat; Long bones.

\section{INTRODUCTION}

Sheep and goats belong to the tribe Caprini of the family Bovidae in the sub-order Ruminantia of the order Artiodactyla (Zeuner, 1963; Epstein, 1971; Corbet, 1978; Corbet \& Hill, 1980; Ryder, 1984). The tribe Caprini is comprised of five genera. Two of these genera, Capra and Heniitragus, are true goats; one genus, Ovis, is the sheep; Other two genera, Ammotragus and Pseudois are goat-like sheep or sheep-like goats (Wilson, 1991).

Although there are considerable numbers of morphological differences between the two species, the most simple and effective visual way of distinguishing sheep from goats is the carriage of the tail. In all domestic forms, goats' tails are erect while those of sheep are pendent (Ryder). The male goats also have beard and caudal (tail) scent glands while in the sheep, the male have a mane with long hair and horn. The female goats have horns and long neck while in sheep the female lack horn and are usually longer than the male in body form (Wilson). Other extant data on the use of body measurements in differentiating small ruminants include lengths of hip and fore limb as well as height of the rump and wither (Afolayan et al., 2006; Salako, 2006a; 2006b).

The differentiation of their remains in a zooarchaeological survey and wild species may be difficult since all the aforementioned criteria were for live or not yet flayed slaughtered animals and domesticated species. In humans, differentiation of races from skeletal observations has provided a central theme in anthropology since its

\footnotetext{
* Department of Anatomy, Faculty of Veterinary Medicine, Ahmadu Bello University, Zaria, Nigeria.

** Department of Anatomy, Faculty of Veterinary Medicine, University of Abuja, Abuja, Nigeria.
} 
SALAMI, S. O.; IBE, C. S.; UMOSEN, A. D.; AJAYI, I. E.\& MAIDAWA, S. M. Comparative osteometric study of long bones in Yankasa sheep and red Sokoto goats. Int. J. Morphol., 29(1):100-104, 2011.

emergence as a discipline (Peter \& Rogers, 1980). The skeletal system stands out as one of the body structures that has been used and still being used for the characterization of different species of animals including humans (Watson, 1972; Guintard \& Lallemand, 2003). This is because most of the parameters considered such as shape, height, length and size are easily accessible in the skeleton. This study was therefore, conducted to compare morphometrically, the long bones of Yankasa sheep and Red Sokoto goats for easy differentiation of their remains and for comparative studies.

\section{MATERIAL AND METHOD}

Specimen collection. Thirty animals (15 sheep and 15 goats) of both sexes and estimated age of one year, bought from middle men at Zaria abattoir were used. The sheep were of Yankasa breed while the goats were of Red Sokoto breed. This is because they are the predominant breeds in North Central zone of Nigeria where the study was conducted. Physical examination of all animals revealed no sign of limb deformity. The animals were slaughtered using standard humane procedures and the limbs harvested.

Preparation of specimen for maceration. The soft tissues attached to the long bones such as muscles, fascia, tendons and ligaments were removed using the scapel. The specimens were then arranged into two macerating buckets (one for sheep and the other for goat limbs). Tap water was added to submerge the specimen. This was allowed to stand for 3 days after which the water was changed. To the changed water, 1-1.5Molar Potassium hydroxide (KOH) was dissolved to facilitate total removal of the remaining soft tissues from the bones. The macerated bones were dried for 2-3 days after which they were boiled with detergent to remove bone marrow and fats. The bones were allowed to dry for the second time, bleached with Hydrogen peroxide $\left(\mathrm{H}_{2} \mathrm{O}_{2}\right)$ and washed with vim and brush. They were dried for 2-3 days. Thereafter, detached articular cartilages during the maceration process were fixed back using glue.

Measurement of the bones. The weights of the bones were taken in grams using a sensitive electronic balance (Mettler balance P 1210, Mettler instrument AG. Switzerland; sensitivity: $0.001 \mathrm{~g}$ ). The lengths of all the bones were measured in centimeters using a thread. The readings were taken by stretching the measured length of the thread against a ruler. Diameter of the bone extremities and the mid-shaft were measured in centimeters using vernier calliper. All recorded weights, lengths and diameters were expressed as mean \pm SEM (Standard Error of Mean) and subjected to statistical analysis using Statistical Package for Social
Sciences (SPSS) version 17.0. Paired sample t-test at $95 \%$ confidence interval was used to determine the level of significant difference in values between the two species. Values of $\mathrm{p}<0.05$ were considered significant, $\mathrm{p}<0.01$ were considered very significant and $\mathrm{p}<0.001$ were considered very highly significant.

\section{RESULTS}

Table I presented the weight of long bones in the two species. There was no significant difference $(p>0.05)$ in the ulna weight between Yankasa sheep and Red Sokoto goats. However, the differences in weights of other long bones between the two species were statistically significant at varying probabilities, with the Yankasa sheep being heavier than the Red Sokoto goat.

Table II presented the lengths of the long bones in the two species. The lengths of all these long bones were of a very high statistical difference $(p<0.001)$ with the Yankasa sheep being longer. This is a very good means of differentiating the remains of the Yankasa Sheep and the Red Sokoto goat.

Table III presented the diameters of the proximal extremities of the long bones in the two species. The difference in diameter of proximal extremity of the femur is not statistically significant $(\mathrm{p}>0.05)$. Conversely, the differences in the proximal extremity of other long bones were of statistical importance at varying degree of probabilities, with that of the Yankasa sheep being wider than the Red Sokoto goat.

Table IV presented the diameter of the mid-shafts of long bones in the two species. The differences in the midshaft diameter of the humerus, metacarpal III, femur, tibia and metatarsal III between the Yankasa sheep and the Red Sokoto goat were very highly significant statistically $(\mathrm{p}<$ 0.001), with the Yankasa sheep being wider than the Red Sokoto goat. Furthermore, the differences in the mid-shaft diameters of the radius and ulna between the two species were statistically significant $(\mathrm{p}<0.05)$.

Table $\mathrm{V}$ presented the diameters of the distal extremities of the long bones in the two species. The diameters of the distal extremity of the humerus, ulna and femur are of no statistical significance $(p>0.05)$. However, the diameters of the distal extremities of the radius, metacarpal III, tibia and metatarsal III were of a very high statistical difference $(\mathrm{p}<0.001)$ between the two species with that of the Yankasa sheep being significantly wider than that of the Red Sokoto goat. 
Table I. Mean ( \pm SEM) weights of Yankasa sheep and Red Sokoto goat limbs in grams.

\begin{tabular}{lccccccc}
\hline Specie & Humerus & Radius & Ulna & Metacarpal III & Femur & Tibia & Metatarsal III \\
\hline Yankasa & 34.627 & 26.700 & 22.467 & 18.740 & 38.740 & 36.360 & 17.567 \\
Sheep & \pm 0.695 & \pm 0.283 & \pm 0.198 & \pm 0.243 & \pm 0.225 & \pm 0.327 & \pm 0.366 \\
Red Sokoto & 30.240 & 25.647 & 22.153 & 17.920 & 36.733 & 32.927 & 15.133 \\
Goat $(\mathrm{n}=15)$ & $\pm 0.728^{* *}$ & $\pm 0.327^{*}$ & $\pm 0.241^{\mathrm{NS}}$ & $\pm 0.209^{*}$ & $\pm 0.317^{* *}$ & $\pm 0.217^{* * *}$ & $\pm 0.234^{* * *}$ \\
\hline
\end{tabular}

NS Non significant difference $(\mathrm{p}>0.05)$; Significant difference $(\mathrm{p}<0.05)$; ** High significant difference $(\mathrm{p}<0.01)$; *** Very high significant difference $(\mathrm{p}<0.001)$.

Table II. Mean ( \pm SEM) lengths of Yankasa sheep and Red Sokoto goat limbs in centimeters.

\begin{tabular}{lccccccc}
\hline Specie & Humerus & Radius & Ulna & Metacarpal III & Femur & Tibia & Metatarsal III \\
\hline Yankasa & 14.433 & 23.173 & 23.527 & 16.427 & 16.280 & 17.793 & 15.280 \\
Sheep & \pm 0.179 & \pm 0.251 & \pm 0.256 & \pm 0.209 & \pm 0.188 & \pm 0.258 & \pm 0.148 \\
Red Sokoto & 12.960 & 19.327 & 20.940 & 13.447 & 14.360 & 16.340 & 13.587 \\
Goat $(\mathrm{n}=15)$ & $\pm 0.114^{* * * *}$ & $\pm 0.186^{* * * *}$ & $\pm 0.154^{* * *}$ & $\pm 0.132^{* * * *}$ & $\pm 0.201^{* * * *}$ & $\pm 0.117^{* * * *}$ & $\pm 0.124^{* * * *}$ \\
\hline
\end{tabular}

*** Very high significant difference $(\mathrm{p}<0.001)$.

Table III. Mean ( \pm SEM) proximal diameters of Yankasa sheep and Red Sokoto goat limbs in centimeters.

\begin{tabular}{lccccccc}
\hline Specie & Humerus & Radius & Ulna & Metacarpal III & Femur & Tibia & Metata rsal III \\
\hline Yankasa & 2.338 & 2.283 & 1.501 & 2.006 & 2.349 & 2.149 & 1.9923 \\
Sheep & \pm 0.021 & \pm 0.042 & \pm 0.02 & \pm 0.030 & \pm 0.023 & \pm 0.016 & \pm 0.023 \\
Red Sokoto & 1.833 & 2.176 & 1.060 & 1.737 & 2.279 & 1.910 & 1.880 \\
Goat $(\mathrm{n}=15)$ & $\pm 0.070^{* * *}$ & $\pm 0.031^{*}$ & $\pm 0.020^{* * *}$ & $\pm 0.020^{* * *}$ & $\pm 0.023^{\text {NS }}$ & $\pm 0.029^{* * *}$ & $\pm 0.021^{* *}$ \\
\hline
\end{tabular}

NS Non significant difference $(\mathrm{p}>0.05) ; *$ Significant difference $(\mathrm{p}<0.05) ; * *$ High significant difference $(\mathrm{p}<0.01) ; * * *$ Very high significant difference $(\mathrm{p}<0.001)$.

Table IV. Mean ( \pm SEM) mid-shaft diameters of Yankasa sheep and Red Sokoto goat limbs in centimeters.

\begin{tabular}{lccccccc}
\hline Specie & Humerus & Radius & Ulna & Metacarpal III & Femur & Tibia & Metatars al III \\
\hline Yankasa & 1.579 & 1.495 & 1.136 & 1.710 & 1.662 & 1.454 & 1.456 \\
Sheep & \pm 0.03 & \pm 0.020 & \pm 0.046 & \pm 0.019 & \pm 0.025 & \pm 0.016 & \pm 0.011 \\
Red Sokoto & 1.369 & 1.447 & 0.985 & 1.485 & 1.472 & 1.324 & 1.329 \\
Goat $(\mathrm{n}=15)$ & $\pm 0.026^{* * *}$ & $\pm 0.017^{*}$ & $\pm 0.019^{*}$ & $\pm 0.014^{* * *}$ & $\pm 0.013^{* * *}$ & $\pm 0.017^{* * *}$ & $\pm 0.015^{* * *}$ \\
\hline
\end{tabular}

*** Very high significant difference $(\mathrm{p}<0.001) ; *$ Significant difference $(\mathrm{p}<0.05)$.

Table V. Mean ( \pm SEM) distal diameters of Yankasa sheep and Red Sokoto goat limbs in centimeters.

\begin{tabular}{lccccccc}
\hline Specie & Humerus & Radius & Ulna & Metacarpal III & Femur & Tibia & Metatarsal III \\
\hline Yankasa & 1.769 & 1.784 & 1.156 & 1.942 & 2.180 & 2.042 & 1.897 \\
Sheep & \pm 0.043 & \pm 0.023 & \pm 0.015 & \pm 0.028 & \pm 0.026 & \pm 0.022 & \pm 0.023 \\
Red Sokoto & 1.741 & 1.413 & 1.109 & 1.570 & 2.108 & 1.815 & 1.718 \\
Goat $(\mathrm{n}=15)$ & $\pm 0.075^{\mathrm{NS}}$ & $\pm 0.017^{* * * *}$ & $\pm 0.018^{\mathrm{NS}}$ & $\pm 0.022^{* * * *}$ & $\pm 0.013^{\mathrm{NS}}$ & $\pm 0.035^{* * *}$ & $\pm 0.020^{* * * *}$ \\
\hline
\end{tabular}

*** Very high significant difference; NS Non significant difference $(\mathrm{p}>0.05)$

\section{DISCUSSION}

It is an established fact that bone growth in weight and length depends primarily on the amount of calcium salt deposited during ossification (Richardson et al., 1976). This in turn depends on the quantity of this mineral in animal feed and the ability of the animal to use the mineral for bone calcification (Sivachelvan et al., 1996). It is therefore, pertinent to point out that the nutritional status of animals from which the bone specimens were collected were unknown. The results of this study however, showed that long bones of Yankasa sheep are generally heavier, longer and greater than those of Red Sokoto goats in all the parameters measured. The differences in length of all the 
bones measured were of a very high statistical significance $(\mathrm{p}<0.001)$. This finding can be related to specie differences in that the state of growth and development of bone in different species varied over a wide limit (Harris, 1937). This range of bone development is from extreme prematurity, as in rat and humans to extreme post-maturity as found in ruminants (Bryden et al., 1972).

Several factors had been reported to influence both the development and growth of bone tissue. Vaughan (1980) listed these factors which were divided into two main groups: Endogenous (genetic and hormonal) and Exogenous (environmental and dietary) factors. These two broad factors also interact with each other to affect bone development and growth (Lawrence \& Fowler, 1997). Of these factors, the endogenous factor is of more relevance to this study since as stated earlier that the nutritional status of the animals used was not considered. In this case the differences in the measurements taken from the long bones of the two species are based on genetic and the intrinsic growth factors inherent in the two species.

In this study, long bones of Yankasa sheep were significantly longer than that of Red Sokoto goats. Also, the mid shaft diameters of these bones were found in the Yankasa sheep to be significantly wider than that of the Red Sokoto goats. This high osteometric value of long bones in Yankasa sheep relative to Red Sokoto goat is a genetic factor due to breed disposition. Thus, it is expected to be constant for healthy ruminants of these two breeds.

In conclusion, this study has demonstrated a means of differentiating long bones from the remains of Yankasa sheep and Red Sokoto goats.

SALAMI, S. O.; IBE, C. S.; UMOSEN, A. D.; AJAYI, I. E. \& MAIDAWA, S. M. Estudio osteométrico comparativo de los huesos largos entre oveja Yankasa y las cabras rojas Sokoto. Int. J. Morphol., 29(1):100-104, 2011.

RESUMEN: Se realizó un estudio morfométrico en los huesos largos en las dos razas predominantes de pequeños rumiantes del norte de Guinea, zona de Sabana de Nigeria, para determinar sus diferencias anatómicas y proporcionar un medio de que permita diferenciar los restos, de estas dos especies, durante los estudios zooarqueológico y en además en práctica de anatómica. Se utilizaron los miembros pélvicos y pectorales de treinta animales (15 ovejas Yankasa y 15 cabras rojas de Sokoto) de ambos sexos. Los huesos largos de los miembros pectorales considerados fueron: húmero, radio, ulna y III metacarpiano, mientras que en los miembros pélvicos fueron: fémur, fíbula y el III metatarso. Los parámetros considerados fueron los pesos medios, longitudes y diámetros de la extremidad proximal y tercios medio y distal de estos huesos. Los resultados mostraron que existe una diferencia altamente significativa ( $p<0,001)$ en la longitud de los huesos largos entre las dos especies. Los huesos en las ovejas Yankasa son significativamente más largos que los de la cabra roja de Sokoto. Además, de las diferencias en el peso, así como los diámetros de los ejes proximal, media y distal de la fíbula entre las dos especies son estadísticamente significativos $(\mathrm{p}<0,001)$. Por el contrario, las diferencias en los diámetros proximal y distal del fémur entre las dos especies no son estadísticamente significativas ( $\mathrm{p}>0,05)$. Fueron discutidos los factores que pueden ser responsables de estas diferencias. Se concluye que los huesos de las ovejas y cabras Yankasa Red Sokoto, se pueden diferenciar por la disparidad en la longitud de los huesos largos o en la morfometría de la tibia.

PALABRAS CLAVE: Oveja Yankasa; Cabra roja; Huesos largos.

\section{REFERENCES}

Afolayan, R. A.; Adeyinka, I. A. \& Lakpini, C. A. M. The estimation of live weight from body measurements in Yankasa sheep. Czech J. Anim. Sci., 51:343-8, 2006.

Bryden, M. M.; Evans, H. E. \& Binns, W. Embryology of sheep. I. Extraembryonic membranes and the development of body form. J. Morphol., 138:169-85, 1972.

Corbet, G. B. The mammals of the Palaearctic Region. A taxonomic Review. London, British Museum (Nat. Hist.) Cornell University Press, 1978.

Corbet, G. B. \& Hill, J. E. A World List of Mammalian Species. London, British Museum (Nat. Hist.), 1980.
Epstein, H. The origin of the Domestic Animals of Africa. New York, Africana Publishing Corporation, 1971.

Guintard, C. \& Lallemand, M. Osteometric study of metapodial bones in sheep (Ovis aries, L. 1758). Ann. Anat., 185:573-83, 2003.

Harris, H. A. The foetal growth of the sheep. J. Anat., 71:51727, 1937.

Lawrence, T. L. J. \& Fowler, V. R. Supportive connective tissue. In: Bone and cartilages. CAB Internet Wallingford Oxon UK, 1997. pp. 36-49. 
Peter, L. W. \& Rogers, W. Osteology. In: Gray's Anatomy. New York Churchhill Livingstone, 1980. pp.236-69.

Richardson, C.; Herbert, C. N. \& Terlecki, S. Estimation of the developmental age of the ovine fetus and lamb. Vet. Rec., 99:22-6, 1976.

Ryder, M. L. Sheep. In: Evolution of Domesticated Animals. Mason, I. L. (Ed) London, Longman, 1984.

Salako, A. E. Principal component factor analysis of the morphostructure of immature Uda sheep. Int. J. Morphol., 24:571-4, 2006a.

Salako, A. E. Application of morphological indices in the assessment of type and function in sheep. Int. J. Morphol., 24:13-8, $2006 \mathrm{~b}$.

Sivachelvan, M. N.; Ghali, M. \& Chibuzo, G. A. Foetal age estimation in sheep and goats. Small Rumin. Res., 19: 69-76, 1996.

Vaughan, J. M. The physiology of bone. London. New York Oxford University press., 1980. pp. 158-65.

Watson, J. P. N. Fragmentation analysis of animal bone samples from archaeological sites. Archaeometry, 14:221-8, 1972.

Wilson, R. T. Small Ruminant Production and the Small Ruminant Genetic Resource in Tropical Africa. Food and Agriculture organization of the United Nations, Rome, 1991.

Zeuner, F. E. A History of Domesticated Animals. London, Hutchinson, 1963.
Correspondence to:

S. O. Salami

Department of Anatomy

Faculty of Veterinary Medicine

Ahmadu Bello University

Zaria,

NIGERIA

Tel.: +2348030681730

E-mail: salamiwoye@yahoo.com

Received: 04-12-2009

Accepted: 28-11-2010 